ARTICLE

\title{
Acute hyperosmotic stress test for vigor assessment of first-feeding larvae of spotted sand bass Paralabrax maculatofasciatus and spotted rose snapper Lutjanus guttatus
}

Prueba de estrés hiperosmótico agudo para evaluar el vigor de larvas a la primera alimentación de la cabrilla arenera Paralabrax maculatofasciatus y del pargo flamenco Lutjanus guttatus

\author{
Juan M. Martínez-Brown ${ }^{*}$, Leonardo Ibarra-Castro², Angel H. Rojo-Cebreros ${ }^{2}$, \\ Jonathan López-Cabanillas ${ }^{2}$, Mariana Rodríguez-Trejo ${ }^{3}$ and José L. Ortíz-Galindo ${ }^{3}$
}

${ }^{1}$ CONACYT-Centro de Investigación en Alimentación y Desarrollo (CIAD), Unidad Mazatlán, Av. Sábalo-Cerritos s/n, Mazatlán, C.P. 82010, A.P. 711, Sinaloa, México. *Corresponding author: jmmartinezbrown@gmail.com

${ }^{2}$ Laboratorio de Reproducción y Planta Piloto CIAD Unidad Mazatlán, Mazatlán, Sinaloa, México

${ }^{3}$ Instituto Politécnico Nacional-CICIMAR, Av. IPN s/n, Col. Playa Palo de Santa Rita, La Paz, C.P. 23096, Baja California Sur, México

Resumen.- En este estudio se investigó la tolerancia de larvas a la primera alimentación de la cabrilla arenera Paralabrax maculatofasciatus y del pargo flamenco Lutjanus guttatus a un estrés hiperosmótico agudo. Embriones de $P$. maculatofasciatus y L. guttatus fueron incubados en microplacas de 48 celdas a 23 y $28^{\circ} \mathrm{C}$, respectivamente. Larvas de primera alimentación fueron expuestas por triplicado a salinidades de 35 a $95 \mathrm{~g} \mathrm{~L}^{-1}$ ó 35 a $85 \mathrm{~g} \mathrm{~L}^{-1}$, y la supervivencia fue monitoreada de 0,5 a 3,5 h ó 0,5 a 53 h, para $P$. maculatofasciatus y L. guttatus, respectivamente. Los resultados mostraron que la mortalidad aumentó de manera diferente entre los tratamientos desde el primer tiempo de exposición en cada especie. Salinidades extremas fueron letales en $30 \mathrm{~min}$. Salinidades cercanas al control fueron sub-letales. En salinidades intermedias, la mortalidad se ajustó a un modelo potencial o lineal. Para $P$. maculatofasciatus, los valores de $\mathrm{LC}_{50}$ obtenidos entre 0,5 y 3,5 h fueron de 73,4 a $65,4 \mathrm{~g} \mathrm{~L}^{-1}$. Para L. guttatus los valores de $\mathrm{LC}_{50}$ obtenidos entre 2 y 5 h fueron de 57,3 a 54,5 $\mathrm{g} \mathrm{L}^{-1}$. La comparación de $\mathrm{LC}_{50}$ entre especies mostró que las larvas de $P$. maculatofasciatus tuvieron una mayor tolerancia al estrés hiperosmótico. Con base en los resultados obtenidos en cada especie, se recomienda la exposición a $70 \mathrm{~g} \mathrm{~L}^{-1}$ por $1 \mathrm{~h}$ para P. maculatofasciatus y $57 \mathrm{~g} \mathrm{~L}^{-1}$ por $2 \mathrm{~h}$ para L. guttatus, cuando se realicen pruebas de estrés hiperosmótico. Esta prueba de estrés es objetiva, sencilla y puede utilizarse tanto en estudios sobre nutrición y manejo de reproductores como en plantas de producción de juveniles como método de control de calidad.

Palabras clave: Calidad de larvas, estrés osmótico, prueba de estrés, tolerancia a la salinidad, análisis Probit

Abstract.- This study investigated the tolerance of first-feeding larvae of spotted sand bass Paralabrax maculatofasciatus and spotted rose snapper Lutjanus guttatus to acute hyperosmotic stress. P. maculatofasciatus and L. guttatus embryos were incubated in 48 -well microplates at 23 and $28^{\circ} \mathrm{C}$, respectively. The first-feeding larvae were exposed in triplicate to salinities of 35 to $95 \mathrm{~g} \mathrm{~L}^{-1}$ or 35 to $85 \mathrm{~g} \mathrm{~L}^{-1}$, and survival was monitored from 0.5-3.5 h or 0.5-53 h, for P. maculatofasciatus and L. guttatus, respectively. The results showed that mortality increased differently among treatments from the first exposure time in each species. Extreme salinities were lethal in $30 \mathrm{~min}$. Salinities close to the control were sub lethal. At intermediate salinities, mortality was fitted to a potential or linear model. For $P$. maculatofasciatus, the LC $_{50}$ values obtained between 0.5 and $3.5 \mathrm{~h}$ were 73.4 to $65.4 \mathrm{~g} \mathrm{~L}^{-1}$. For L. guttatus the $\mathrm{LC}_{50}$ values obtained between 2 and $5 \mathrm{~h}$ were 57.3 to $54.5 \mathrm{~g} \mathrm{~L}^{-1}$. Comparison of $\mathrm{LC}_{50}$ between species showed that $P$. maculatofasciatus larvae had a higher tolerance to hyperosmotic stress. Based on the results for each species, it is recommended to expose to $70 \mathrm{~g} \mathrm{~L}^{-1}$ for $1 \mathrm{~h}$ for $P$. maculatofasciatus and 57 $\mathrm{g} \mathrm{L}^{-1}$ for $2 \mathrm{~h}$ for $\mathrm{L}$. guttatus when conducting hyperosmotic stress tests. This stress test is objective, simple, and can be used in both studies on broodstock nutrition and management and in hatcheries as a quality control method.

Key words: Larvae quality, osmotic stress, stress test, salinity tolerance, Probit analysis 


\section{INTRODUCTION}

In larviculture of marine fishes high mortalities occur during the endogenous to exogenous feeding transition (Yúfera \& Darías 2007). These high mortalities can occur in larvae from embryo batches characterized as high quality (e.g., high hatching rates and high survival of larvae at first-feeding stage) (Duncan 2013). Therefore, it is necessary to develop practical and reliable criteria for the assessment of the first-feeding larvae quality in terms of physiological condition or vigor. Vigor tests based on stress tolerance have been developed (Lavens et al. 1995). Such tests are based on increases in the metabolic demand of energy caused by the stressor to maintain homeostasis. Therefore, mortality caused by acute exposure to a stressor for a specific period of time shows the vigor of the organism in real time (Dhert et al. 1992). Several stressors have been used in acute stress tests (e.g., starvation, air exposition, and temperature), which acute change in salinity has proven to be the most simple, controllable and reliable (Dhert et al. 1992). Saline stress tests have been used to test the quality of larvae or juveniles of mollusks (Maguire et al. 1999), crustaceans (Samocha et al. 1998), and fishes (Kjørsvik et al. 2003, Jelkiæ et al. 2014). Saline stress tests have not yet been conducted on first-feeding larvae of marine fishes because they are very susceptible to mechanical stress caused by handling during stress tests. However, quality assessment at this stage is important because structural and energetic resources from the yolk have been depleted and incorporated into the larval body. Therefore, hyperosmotic (high salinity) stress tolerance is a reliable indicator of the first-feeding larvae vigor.

An alternative incubation method that avoids mechanical stress and allows fast, easy and accurate monitoring of many first-feeding larvae is stocking embryos individually in multiwell culture microplate (Panini et al. 2001). This method of incubation presents an opportunity to develop a simple method to assess the vigor of first-feeding larvae by the determination of tolerance to acute hyperosmotic stress using robust statistics, such as the median lethal concentration $\left(\mathrm{LC}_{50}\right)$ and median lethal time $\left(\mathrm{LT}_{50}\right)$ from Probit analysis. Spotted sand bass (Paralabrax maculatofasciatus) and spotted rose snapper (Lutjanus guttatus) are important species for artisanal and sport fisheries in the Eastern Central Pacific (Froese \& Pauly 2016). Due to their high demand in Latin America and to over-exploitation of wild populations (Arreguín-Sánchez \& Arcos-Huitrón 2011), research has focused on the development of technology for juvenile production of both species in captivity (Civera-Cerecedo et al. 2002, Alvarez-Lajonchère \& Puello-Cruz 2011).

Therefore, the goal of this study was to investigate the tolerance of first-feeding larvae of these species to acute hyperosmotic stress, to select a level of salinity and exposure time that can be used for a simple vigor test. For this purpose, the $\mathrm{LC}_{50}$ at different exposure times to acute hyperosmotic stress, and $\mathrm{LT}_{50}$ at different salinities were determined. This quality criteria will be useful for studies aimed at optimizing the processes that affect larvae quality at the onset of first feeding (e.g., broodstock management and nutrition), or in experimental larviculture of both species.

\section{MATERIALS AND METHODS}

\section{BROODSTOCK HUSBANDRY}

Wild broodstock of P. maculatofasciatus (24 males: $172 \pm$ 20 g; 36 females: $173 \pm 17$ g) were caught in Bahia de La Paz, Baja California Sur, Mexico and were kept in six 1,100L cylindrical tanks connected to a recirculation system with environmental control at the Laboratory of Experimental Biology, CICIMAR-IPN, La Paz, Mexico. Environmental conditions were (mean $\pm \mathrm{SD}$ ): flow, $20.1 \mathrm{~L}$ min $^{-1}$; temperature, $21.3 \pm 0.6^{\circ} \mathrm{C} ; \mathrm{NH}_{3}+\mathrm{NH}_{4}^{+}, 0.2 \pm 0.1 \mathrm{mg}$ $\mathrm{L}^{-1} ; \mathrm{NO}_{2}, 0.02 \pm 0.02 \mathrm{mg} \mathrm{L}^{-1}$; salinity, $35 \pm 0.7 \mathrm{~g} \mathrm{~L}^{-1}$; dissolved oxygen, $6 \pm 1 \mathrm{mg} \mathrm{L}^{-1}$; photoperiod, 13L:11D; sex rate, 1.5 female: 1 male; stoking density, $2.7 \mathrm{~kg} \mathrm{~m}^{-3}$. The fish were hand-fed once per day to apparent satiation with frozen whole juvenile fish (Eucinostomus spp.). Under these conditions, reproduction was induced.

Wild broodstock of L. guttatus (20 males: $1668 \pm 269$ g; 11 females: $1803 \pm 368 \mathrm{~g}$ ) were caught in Sayulita, Nayarit, Mexico and were kept in 18,000-L cylindrical tanks at the Pilot Hatchery of CIAD, Mazatlan, Mexico. The tank was supplied with a seawater flow-through system $\left(75 \mathrm{~L} \mathrm{~min}^{-1}\right)$ and aeration (60 $\mathrm{L} \mathrm{min}^{-1}$ ) (Ibarra-Castro \& ÁlvarezLajonchère 2011) and the natural environmental conditions were as follows (mean $\pm \mathrm{SD}$ ): temperature, $30 \pm 0.9^{\circ} \mathrm{C}$; salinity, $35 \mathrm{~g} \mathrm{~L}^{-1}$; $\mathrm{O}_{2}, 6 \mathrm{mg} \mathrm{L}^{-1}$; photoperiod, 12L:11D; sex rate, 1 female: 1.8 male; stoking density, $2.9 \mathrm{~kg} \mathrm{~m}^{-3}$. The broodstock were hand-fed on alternate days to apparent satiation with squid (Loligo sp.), skipjack tuna (Katsuwonus pelamis), and shrimp (Xiphopenaeus sp.) in equal proportions. In these fish, reproduction occurred without hormonal treatment. 


\section{INCUBATION AND ASSESSMENT OF EMBRYO QUALITY}

Embryos from voluntary spawning of both species were collected, cleaned and separated by buoyancy in a graduated cylinder and gently rinsed with UV-sterilized seawater. Subsequently, embryos were randomly selected and transferred into flat-bottom 48-well microplate (one embryo per well) fitted with a low evaporation lid (Cellstar ${ }^{\circledR}$, Greiner Bio-One, Monroe, USA). Each well was filled with $0.5 \mathrm{~mL}$ UV-sterilized seawater (35 $\left.\mathrm{g} \mathrm{L}^{-1}\right)$. Microplates were immediately placed in an incubator with a controlled temperature at $23 \pm 0.5^{\circ} \mathrm{C}$ and $28 \pm 0.5^{\circ} \mathrm{C}$ for $P$. maculatofasciatus and L. guttatus, respectively. During incubation, the photoperiod (13L:11D) was maintained by cool white fluorescent lamps (500 lx). To monitor the embryonic development and survival, microplates were examined every day using a stereomicroscope (SZ40, Olympus ${ }^{\circledR}$, Tokyo, Japan), until pigmentation of eyes and complete yolk absorption were observed (first-feeding stage: $76 \mathrm{~h}$ for $P$. maculatofasciatus and $68 \mathrm{~h}$ for $L$. guttatus). For each microplate, hatching and survival to first-feeding stage were calculated as percentage of the initial number of eggs.

\section{EXPERIMENTAL DESIGN}

Once the first-feeding stage was reached, acute hyperosmotic stress tests were initiated. The $P$. maculatofasciatus first-feeding larvae were exposed to salinities of 35 (control), 50, 65, 80, and $95 \mathrm{~g} \mathrm{~L}^{-1}$. The $L$. guttatus first-feeding larvae were exposed to salinities of 35 (control), 45, 55, 65, 75, and $85 \mathrm{~g} \mathrm{~L}^{-1}$. Each saline concentration was achieved by adding $0.5 \mathrm{~mL}$ of brine (specifically adjusted by the dissolution of synthetic salt [Instant Ocean ${ }^{\circledR}$, Vancouver, USA] in UV-sterilized seawater) into each well of three microplates for each saline treatment. Each microplate was one experimental unit; therefore, each treatment had an average of 135 firstfeeding larvae (subtracting mortality at bioassay onset). The control treatment ( $35 \mathrm{~g} \mathrm{~L}^{-1}$ ) was prepared by adding UV-sterilized seawater. To avoid thermal shock, brine solutions were placed in an incubator for 30 min prior to exposure at 23 and $28^{\circ} \mathrm{C}$, for $P$. maculatofasciatus and $L$. guttatus, respectively. Microplates were again placed in the incubator immediately after the addition of brine. The larvae survival of $P$. maculatofasciatus from each microplate was monitored at $0.5 ; 1 ; 1.5 ; 2 ; 2.5 ; 3$; and 3.5 $\mathrm{h}$, whereas the larvae survival of $L$. guttatus was monitored at $0.5 ; 1.3 ; 1.5 ; 1.7 ; 2 ; 3 ; 4 ; 11.8 ; 17.7 ; 41.5$; and 53 h. Larvae were considered dead when they displayed no movement in response to a slight mechanical stimulus.
At the end of each experiment, salinity was measured in each of the 48 wells by a temperature-compensated refractometer (SR5-AQ, China) to verify the salinity.

\section{STATISTICAL METHODS}

Results are reported as the mean \pm SD (standard deviation) from three replicates. Cumulative mortality from each salinity treatment throughout the exposure time was fitted to regression models. Differences among salinity treatments for each exposure time were tested by a oneway ANOVA, followed by a Tukey's post-hoc test using arcsine-square-root-transformed data. The significance level was fixed at 0.05 . These analyses were performed using SigmaPlot $11^{\circledR}$ (Systat Software, San Jose, USA). $\mathrm{LC}_{50}$ for each exposure time and $\mathrm{LT}_{50}$ for each salinity, and their respective fiducial limits were determined with Probit analyses using PASW ${ }^{\circledR}$ Statistics 18 (SPSS, IBM, New York, USA).

\section{RESUlts}

The mean coefficient of variation of salinity among wells from each microplate in all treatments for both species was $1.1 \pm 0.2 \%$, which represents a negligible variation from the nominal salinity in each treatment. Overall, the quality of embryos and larvae of both species was high. The hatching rate, survival to hatching, and survival to first-feeding stage for $P$. maculatofasciatus were $99 \pm$ $0.9 \%, 93 \pm 3.6 \%$, and $91 \pm 3.4 \%$, respectively; similar values were observed for L. guttatus, at $99 \pm 1 \%, 98 \pm 2 \%$, and 87 $\pm 14 \%$, respectively. These results demonstrate that the incubation technique in microplates has no adverse effect on the quality determination or embryonic development in either species.

\section{PARALABRAX MACULATOFASCIATUS}

In the control group mortality throughout the experiment was insignificant (2.3\%; Fig. 1). At $50 \mathrm{~g} \mathrm{~L}^{-1}$ mortality gradually increased to $20 \%$ at $3.5 \mathrm{~h}$ after fitting a linear model $\left(y=-1.4241+5.8783 x, r^{2}=0.55\right)$; however, there were no significant differences from the control at any time $(P$ $>0.05)$. At $65 \mathrm{~g} \mathrm{~L}^{-1}$ mortality increased linearly $(y=2.8319$ $\left.+16.1516 x, r^{2}=0.92\right)$ to $58.3 \%$ at $3.5 \mathrm{~h}$ and showed a significant difference from the control at $1 \mathrm{~h}$ of exposure $(P<0.05)$. At $80 \mathrm{~g} \mathrm{~L}^{-1}$, mortality increased exponentially $\left(y=92.4186 x^{0.1983}, r^{2}=0.96\right)$, reaching total mortality at 1.5 $\mathrm{h}$ and only did not show significant differences with the $95 \mathrm{~g} \mathrm{~L}^{-1}$ treatment at any time $(P<0.05)$. At $95 \mathrm{~g} \mathrm{~L}^{-1}$, rapid mortality occurred (100\% in $0.5 \mathrm{~h})$. 


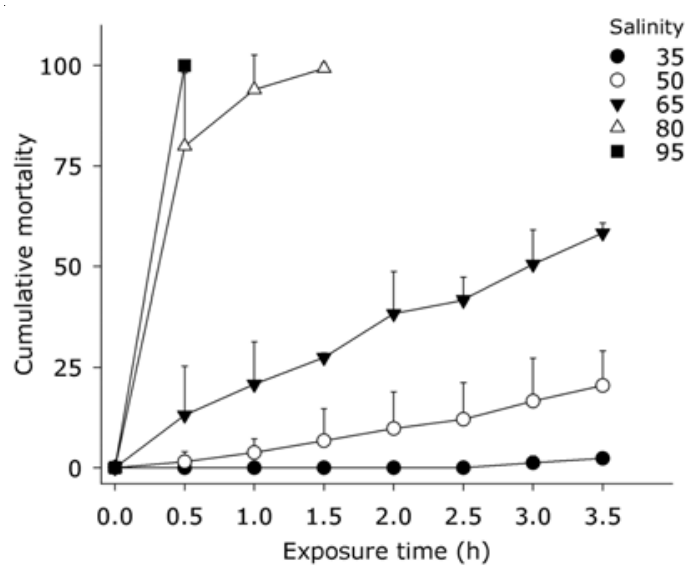

Figure 1. Cumulative mortality (mean \pm SD) of Paralabrax maculatofasciatus first-feeding larvae subjected to hyperosmotic stress using different salinity $\left(\mathrm{g} \mathrm{L}^{-1}\right)$ concentrations and exposure times (h) at $23^{\circ} \mathrm{C} /$ Mortalidad acumulada (promedio \pm desviación estándar) de larvas de Paralabrax maculatofasciatus a la primera alimentación sujetas a estrés hiperosmótico usando diferentes concentraciones de salinidad $\left(\mathrm{g} \mathrm{L}^{-1}\right)$ y tiempos de exposición (h) a $23^{\circ} \mathrm{C}$

The $\mathrm{LC}_{50}$ values decreased as the exposure time increased, from $73.4 \mathrm{~g} \mathrm{~L}^{-1}$ at $0.5 \mathrm{~h}$ to $65.4 \mathrm{~g} \mathrm{~L}^{-1}$ at $3.5 \mathrm{~h}$; however, it is possible that there were no differences in $\mathrm{LC}_{50}$ values after $1 \mathrm{~h}$, given the overlap in the $95 \%$ fiducial limits (Table 1). The $\mathrm{LT}_{50}$ values were estimated only for salinities of 50, 65, and $80 \mathrm{~g} \mathrm{~L}^{-1}$ (Table 1). The Probit model had a good fit to these data (Chi-square test: 0.192, 4 for $50 \mathrm{~g} \mathrm{~L}^{-1}$; 0.529, 4 for $60 \mathrm{~g} \mathrm{~L}^{-1}$; 3.91, 4 for $80 \mathrm{~g} \mathrm{~L}^{-1}$ ).

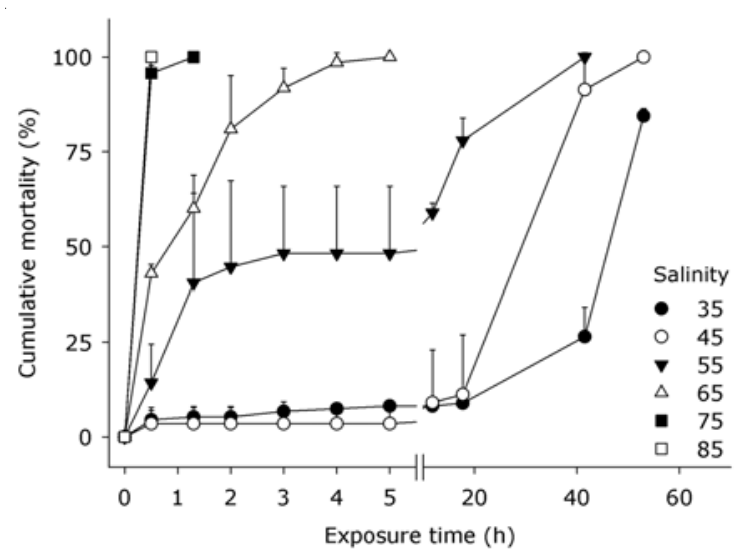

Figure 2. Cumulative mortality (mean $\pm \mathrm{SD}$ ) of Lutjanus guttatus first-feeding larvae subjected to hyperosmotic stress using different salinity $\left(\mathrm{g} \mathrm{L}^{-1}\right)$ concentrations and exposure times $(\mathrm{h})$ at $28^{\circ} \mathrm{C} /$ Mortalidad acumulada (promedio \pm desviación estándar) de larvas de Lutjanus guttatus a la primera alimentación sujetas a estrés hiperosmótico usando diferentes concentraciones de salinidad $\left(\mathrm{g} \mathrm{L}^{-1}\right)$ y tiempos de exposición (h) a $28^{\circ} \mathrm{C}$
Table 1. Parameters of Probit regressions, $\mathrm{LC}_{50}$ and $\mathrm{LT}_{50}$ of Paralabrax maculatofasciatus first-feeding larvae subjected to acute hyperosmotic stress at $23^{\circ} \mathrm{C} /$ Parámetros de regresión Probit, $\mathrm{LC}_{50}$ y $\mathrm{LT}_{50}$ de larvas a la primera alimentación de Paralabrax maculatofasciatus sujetas a estrés hiperosmótico agudo a $23^{\circ} \mathrm{C}$

\begin{tabular}{ccccc}
\hline & $a^{\mathrm{a}}$ & $b^{\mathrm{a}}$ & $\begin{array}{c}\mathrm{LC}_{50}\left(\mathrm{~g} \mathrm{~L}^{-1}\right) \\
\left(95 \% \mathrm{FL}^{\mathrm{b}}\right)\end{array}$ & $P^{\mathrm{c}}$ \\
\hline Time (h) & -43.7180 & 23.4353 & $73.4(71.7-74.9)$ & 0.4 \\
0.5 & -50.7065 & 27.4597 & $70.2(68.6-71.7)$ & 0.9 \\
1 & -64.0783 & 34.9084 & $68.5(67.0-70.0)$ & 0.8 \\
1.5 & -58.1548 & 31.8124 & $67.3(65.8-68.8)$ & 0.9 \\
2 & -57.0846 & 31.2558 & $67.0(65.4-68.6)$ & 0.9 \\
2.5 & -53.1588 & 29.1970 & $66.1(64.3-67.8)$ & 0.9 \\
3 & -49.3091 & 27.1608 & $65.4(63.1-67.1)$ & 0.9 \\
3.5 & & & & \\
Salinity (g L $\left.{ }^{-1}\right)$ & -1.9216 & 1.9325 & $9.9(6.2-80.2)$ & 0.9 \\
50 & -1.3229 & 2.4800 & $3.4(2.7-4.3)$ & 0.9 \\
65 & 1.5778 & 2.3136 & $0.2(0.0-0.8)$ & 0.4 \\
\hline 80 & & & & \\
\hline
\end{tabular}

a Probit $(\mathrm{p})=a+b\left(\log _{10} \mathrm{X}\right) ; P=Z_{(0,1)} \rightarrow P(0.5)=Z(0)$

${ }^{\mathrm{b}}$ Fiducial limits

${ }^{\mathrm{c}} P$-value of Chi-square test for Probit model

\section{LUTJANUS GUTTATUS}

In the control group, mortality increased exponentially $\left(y=1.9287 e^{0.0706 x}, r^{2}=0.95\right)$, from $9 \%$ within $17.6 \mathrm{~h}$, to $26.4 \%$ at $41.5 \mathrm{~h}$, and $84.4 \%$ at $53 \mathrm{~h}$ (Fig. 2). At $45 \mathrm{~g} \mathrm{~L}^{-1}$ mortality increased exponentially $\left(y=7.5335 e^{0.0509 x}, r^{2}=0.88\right)$ and was significantly higher than the control at $41.5 \mathrm{~h}$, reaching $91.3 \%$, and $100 \%$ at $53 \mathrm{~h}(P<0.05)$. At $55 \mathrm{~g} \mathrm{~L}^{-1}$, mortality followed a sigmoid curve with a stable phase from 40.4 to $48.2 \%$ within 1.3 and $5 \mathrm{~h}$, with the highest rate (100\%) after $41.5 \mathrm{~h}$. In this treatment, mortality was significantly higher than in the lower salinities at any time between $1.5 \mathrm{~h}$ and $17.7 \mathrm{~h}(P<0.05)$. At $65 \mathrm{~g} \mathrm{~L}^{-1}$, mortality increased exponentially $\left(y=57.1349 x^{0.4124}, r^{2}=\right.$ 0.88 ), reaching $100 \%$ at $5 \mathrm{~h}$ and was significantly different from the other treatments at any time $(P<0.05)$, except between 1.3 and $2 \mathrm{~h}$ for the $55 \mathrm{~g} \mathrm{~L}^{-1}$ treatment. At 75 and $85 \mathrm{~g} \mathrm{~L}^{-1}$, the effect was extreme with abrupt mortality $(100 \%$ at $0.5 \mathrm{~h}$ ).

The $\mathrm{LC}_{50}$ values of the acute hyperosmotic stress tests were determined only for the first eight exposure times. The highest $\mathrm{LC}_{50}$ values were 63.7 and $59.6 \mathrm{~g} \mathrm{~L}^{-1}$ for 0.5 and $1.3 \mathrm{~h}$, respectively; however, the fiducial limits for these $\mathrm{LC}_{50}$ values were wide and the model had a poor fit (Chi-square test: 36.8, 3 for $0.5 \mathrm{~h}$; 22.7, 3 for $1.3 \mathrm{~h}$ ) (Table 2). After $2 \mathrm{~h}$, with small fiducial limits and a well-fitting model (Chi-square test: 5, 3 for $2 \mathrm{~h} ; 0.57,3$ for $3 \mathrm{~h} ; 2.9$, 3 for $4 \mathrm{~h}$; 6.8, 3 for $5 \mathrm{~h}$; 4.4, 3 for $11.8 \mathrm{~h}$; $0.6,3$ for $17.6 \mathrm{~h}$ ), the $\mathrm{LC}_{50}$ values showed a gradual decrease from $57.3 \mathrm{~g} \mathrm{~L}^{-1}$ at $2 \mathrm{~h}$ to $51.2 \mathrm{~g} \mathrm{~L}^{-1}$ at $17.6 \mathrm{~h}$. The $\mathrm{LT}_{50}$ were determined only for 55 and $65 \mathrm{~g} \mathrm{~L}^{-1}$ (3.9 and $0.7 \mathrm{~h}$, respectively), but they showed a poor fit to the model (Table 2). 
Table 2. Parameters of Probit regressions, $\mathrm{LC}_{50}$ and $\mathrm{LT}_{50}$ of Lutjanus guttatus first-feeding larvae subjected to acute hyperosmotic stress at $28^{\circ} \mathrm{C} /$ Parámetros de regresión Probit, $\mathrm{LC}_{50}$ y $\mathrm{LT}_{50}$ de larvas a la primera alimentación de Lutjanus guttatus sujetas a estrés hiperosmótico agudo a $28^{\circ} \mathrm{C}$

\begin{tabular}{|c|c|c|c|c|}
\hline & $a^{\mathrm{a}}$ & $b^{\mathrm{a}}$ & $\begin{array}{c}\mathrm{LC}_{50}\left(\mathrm{~g} \mathrm{~L}^{-1}\right) \\
\left(95 \% \mathrm{FL}^{\mathrm{b}}\right)\end{array}$ & $P^{c}$ \\
\hline \multicolumn{5}{|l|}{ Time (h) } \\
\hline 0.5 & -33.0124 & 18.2995 & $63.7(49.0-73.2)$ & 0.0 \\
\hline 1.3 & -29.9756 & 16.8830 & $59.6(51.0-66.0)$ & 0.0 \\
\hline 2 & -32.5960 & 18.5377 & $57.3(56.0-58.6)$ & 0.2 \\
\hline 3 & -37.0154 & 21.2011 & $55.7(54.5-56.9)$ & 0.9 \\
\hline 4 & -44.4888 & 25.5938 & $54.7(53.6-55.9)$ & 0.4 \\
\hline 5 & -47.9985 & 27.6476 & $54.5(51.4-57.4)$ & 0.1 \\
\hline 11.8 & -41.9325 & 24.3360 & $52.9(51.7-54.0)$ & 0.2 \\
\hline 17.6 & -44.4620 & 26.0143 & $51.2(50.1-52.3)$ & 0.9 \\
\hline \multicolumn{5}{|c|}{ Salinity $\left(\mathrm{g} \mathrm{L}^{-1}\right)$} \\
\hline 55 & -0.7235 & 1.2075 & $3.9(2.5-6.2)$ & 0.0 \\
\hline 65 & 0.2941 & 2.2877 & $0.7(0.3-1.1)$ & 0.0 \\
\hline
\end{tabular}

\section{Discussion}

This study showed a species-specific differential mortality response of first-feeding larvae at varying stressor intensities (salinity level and exposure time). The results indicated a gradient of individual homeostatic capabilities within the examined population of each species. Extreme salinities were lethal in $30 \mathrm{~min}$, while salinities closest to the control (50 g L-1 for P. maculatofasciatus; $45 \mathrm{~g} \mathrm{~L}^{-1}$ for $L$. guttatus) were sub-lethal over the full exposure time. Moreover, intermediate salinities (65 and $80 \mathrm{~g} \mathrm{~L}^{-1}$ for $P$. maculatofasciatus; 55 and $65 \mathrm{~g} \mathrm{~L}^{-1}$ for L. guttatus) showed progressive mortality patterns. Particularly, L. guttatus larvae exposed at $55 \mathrm{~g} \mathrm{~L}^{-1}$ showed a sigmoidal response with three phases: 1) short lethal phase; 2) mid-duration stable sub-lethal phase; and 3) large exhaustion phase. Mortality in each phase is likely due to a deficit in the capacity of homeostasis and energy depletion caused by osmotic stress. Studies on the early ontogeny of marine fish confirm that high levels of salinity increase the energy cost of osmoregulation (Tseng \& Hwang 2008). In contrast to other levels of salinity, the $55 \mathrm{~g} \mathrm{~L}^{-1}$ level allows us to distinguish clearly between two groups of physiological conditions (vigor) in the L. guttatus larvae experimental population. In P. maculatofasciatus, the amplitude of salinity levels tested in this study did not allow for the observation of a sigmoidal curve as in $L$. guttatus; however, the $\mathrm{LC}_{50}$ values resolve this difficulty. The $\mathrm{LC}_{50}$ values provide a convenient way to compare tolerance between various groups (Van Veld \& Nacci 2008).
Comparison of $\mathrm{LC}_{50}$ and $\mathrm{LT}_{50}$ (particularly at $65 \mathrm{~g} \mathrm{~L}^{-1}$ ) between both species showed that $P$. maculatofasciatus larvae tended to have a higher tolerance to hyperosmotic stress. In contrast, $\mathrm{LC}_{50}$ of $L$. guttatus at $17.6 \mathrm{~h}$ was higher than that reported for first-feeding larvae of Cynoscion nebulosus (18 h-LD $\mathrm{L}_{50}=42.5 \mathrm{~g} \mathrm{~L}^{-1}$; Banks et al. 1991) and Rachycentron canadum (18 h- $\mathrm{LD}_{50}=41.9 \mathrm{~g} \mathrm{~L}^{-1}$; Faulk \& Holt 2006).

The $\mathrm{LC}_{50}$ and $\mathrm{LT}_{50}$ values are conventionally used in toxicology studies as indicators of acute toxicity of a substance (Rand 2008). However, due to the occurrence of values below $50 \%$ of the response corresponding to the sensitive portion of the population, these criteria can also be used as quality indicators. Samocha et al. (1998) proposed a simple method for evaluating the quality of white shrimp larvae Litopenaeus vannamei, based on the $2 \mathrm{~h}-\mathrm{LC}_{50}$ observed from osmotic or formalin shock. These authors note the utility and statistical reliability of Probit analysis to determine $\mathrm{LC}_{50}$. In this analysis, the optimization algorithm of the parameters of the linear regression model determines that fiducial limits are narrower in the middle region (values approximately 50\% of response). Given that the amplitude of fiducial limits is a criterion for selecting the best model (Debanne \& Haller 1985), the $\mathrm{LC}_{50}$ and $\mathrm{LT}_{50}$ estimated in this way are statistically more accurate and reliable. As a result, it was considered the shortest exposure time with a best fit of the Probit regression model in our experiment $\left(1 \mathrm{~h}-\mathrm{LC}_{50}\right.$ is $70 \mathrm{~g} \mathrm{~L}^{-1}$ for P. maculatofasciatus and $2 \mathrm{~h}-\mathrm{LC}_{50}$ was $57 \mathrm{~g} \mathrm{~L}^{-1}$ for $L$. guttatus) as the appropriate benchmark in our hyperosmotic stress tests. However, the $\mathrm{LT}_{50}$ values for both species were inadequate as benchmarks due to a poor fit of the model and wide fiducial limits.

Based on the above, this study proposed the following hyperosmotic stress test to assess the first-feeding larvae vigor of $P$. maculatofasciatus and L. guttatus: 1 ) Incubate embryos in three 48-well microplates and evaluate the quality as described in Materials and methods section for each species; this sample size is sufficient to give statistical power to the test, if considering a population of $1 \times 10^{6}$, an error margin of $10 \%$ and a confidence level of $95 \%$ (sample size estimated to population proportion is 96 specimens). 2) Add $0.5 \mathrm{~mL}$ of brine at $105 \mathrm{~g} \mathrm{~L}^{-1}$ in each well to achieve $70 \mathrm{~g} \mathrm{~L}^{-1}$ for P. maculatofasciatus or $0.38 \mathrm{~mL}$ to achieve $57 \mathrm{~g} \mathrm{~L}^{-1}$ for L. guttatus. 3) Count dead larvae after $1 \mathrm{~h}$ for $P$. maculatofasciatus or $2 \mathrm{~h}$ for $L$. guttatus. If larval survival is equal to or greater than $50 \%$, the quality is comparable or better than that obtained in the present study. 
Other osmotic stress tests have been proposed for marine fish (e.g., Dhert et al. 1992, Kjørsvik et al. 2003). Typically, these tests are conducted by placing 10 specimens in $50 \mathrm{~mL}$ (frequently per triplicate), which are subjected to $70 \mathrm{~g} \mathrm{~L}^{-1}$ (salinity arbitrarily selected) and survival assessment is carried out in short periods (5-15 min). The result is reported as a stress index (sum of cumulative mortalities at each time period) or $\mathrm{LT}_{50}$. Under these operating conditions, the stress test is not suitable for the vigor assessment of first-feeding larvae due to handling, statistically inappropriate sample sizes, salinity levels not selected relative to the tolerance of the target species and impractical frequency survival assessment. These disadvantages are solved by the stress test proposed in this work. This stress test has been used in the routine evaluation of the quality of different batches of first-feeding larvae of L. guttatus (Martínez-Brown et al. unpublished data) and used to determine fatty acids related to first-feeding larvae quality in nutrition studies of $P$. maculatofasciatus broodstock (Rodríguez-Trejo et al. 2009) ${ }^{1}$.

In conclusion, this study recommends a simple method to objectively determine the vigor of first-feeding larvae of P. maculatofasciatus and L. guttatus, based on tolerance to acute hyperosmotic stress. Application of this method to other species is necessary to determine the $\mathrm{LC}_{50}$ at different exposure times for each species, using Probit analysis. However, the salinity of spawning should be considered when determining the $\mathrm{LC}_{50}$, as it affects the larvae tolerance to variation in salinity (Kucera et al. 2002). This test can be used together with other quality criteria of embryos and larvae (biochemical, morphometric, transcriptomics, etc.) to establish interactive relationships and elucidate the maternal contribution in studies of nutrition and management of broodstock. Further studies are required to validate the predictive value of this stress test on zootechnical performance achieved at the end of the larviculture process.

\footnotetext{
${ }^{1}$ Rodríguez-Trejo $M$, JL Ortíz-Galindo, R Civera-Cerecedo, JM Martínez-Brown, MO Rosales-Velázquez \& V Carrasco-Chávez. 2009. Nutrition of Paralabrax maculatofasciatus broodstock II: Effects of arachidonic acid level on the reproductive performance and the quality of embryos and larvae. World Aquaculture 2009, Abstracts, p. 734.
}

\section{ACKNOWLEDGEMENTS}

We thank Luis Ochoa-Bojórquez, Gustavo CervantesÁvila, Alán García-Gómez, Manuel Morales-Plasencia, Andrés Aguirre-Torres, and David López-Martínez for technical assistance. Special thanks Dr. Luis ÁlvarezLajonchère and Dr. Neptalí Morales-Serna for their critical review of the manuscript. The first author would also like to thank project 3285 from Cátedras-CONACYT program.

\section{LITERATURE CITED}

Alvarez-Lajonchère LS \& AC Puello-Cruz. 2011. El pargo flamenco: Lutjanus guttatus, producción controlada de huevos, larvas y juveniles, 169 pp. Clave Editorial, México DF.

Arreguín-Sánchez F \& E Arcos-Huitrón. 2011. La pesca en México: estado de la explotación y uso de los ecosistemas. Hidrobiológica 21: 431-462.

Banks MA, GJ Holt \& JM Wakeman. 1991. Age-linked changes in salinity tolerance of larval spotted seatrout (Cynoscion nebulosus, Cuvier). Journal of Fish Biology 39: 505-514.

Civera-Cerecedo R, JL Ortiz-Galindo, S Dumas, H Nolasco-Soria, CA Alvarez-González, BH AnguasVélez, R Peña, MO Rosales-Velázquez, V CarrascoChávez, R García-Gómez \& E Goytortúa. 2002. Avances en la nutrición de la cabrilla arenera (Paralabrax maculatofasciatus). In: Cruz-Suárez E, D Rieque-Marie, M Tapia-Salazar, MG Gaxiola-Cortés \& N Simoes (eds). Avances en nutrición acuícola, pp. 352-406. VI Simposio Internacional de Nutrición Acuícola, Cancún.

Debanne SM \& HS Haller. 1985. Evaluation of statistical methodologies for estimation of median effective dose. Toxicology and Applied Pharmacology 79: 274-282.

Dhert PH, P Lavens \& P Sorgeloos. 1992. Stress evaluation: a tool for quality control of hatchery-produced shrimp and fish fry. Aquaculture Europe 17: 6-10.

Duncan N. 2013. Principles of finfish broodstock management in aquaculture: control of reproduction and genetic improvement. In: Allan G \& G Burnell (eds). Advances in aquaculture hatchery technology, pp. 23-75. Woodhead Publishing, Oxford.

Faulk CK \& GJ Holt. 2006. Responses of cobia Rachycentron canadum larvae to abrupt or gradual changes in salinity. Aquaculture 254: 275-283.

Froese R \& D Pauly. 2016. FishBase. <http//www.fishbase.org/>

Ibarra-Castro L \& L Alvarez-Lajonchère. 2011. GnRHainduced multiple spawns and volition spawning of captive spotted rose snapper, Lutjanus guttatus, at Mazatlan, Mexico. Journal of the World Aquaculture Society 42: 564574. 
Jelkiæ D, A Opaèak, D Horvat \& R Safner. 2014. Common carp fry survival during salinity stress test: effect of feeding regime. Veterinary Archives 84: 429-438.

Kjørsvik E, K Hoehne-Reitan \& KI Reitan. 2003. Egg and larval quality criteria as predictive measures for juvenile production in turbot (Scophthalmus maximus L.). Aquaculture 227: 9-20.

Kucera CJ, CK Faulk \& GJ Holt. 2002. The effect of parental acclimation to spawning salinity on the survival of larval Cynoscion nebulosus. Journal of Fish Biology 61: 726738.

Lavens P, P Sorgeloos, P Dhert \& B Devresse. 1995. Larval foods. In: Bromage N \& RJ Roberts (eds). Broodstock management and egg and larval quality, pp. 373-397. Blackwell Science, Oxford.

Maguire JA, PG Fleury \& GM Burnell. 1999. Some methods for quantifying quality in the scallop Pecten maximus (L.). Journal of Shellfish Research 18: 59-66.

Panini EB, CC Mylonas, S Zanuy, M Carrillo, J Ramos \& MP Bruce. 2001. Incubation of embryos and larvae of marine fish using microtiter plates. Aquaculture International 9: 189-195.

Rand GM. 2008. Fish toxicity studies. In: Di Giulio RT \& DE Hinton (eds). The toxicology of fishes, pp. 659-682. CRC Press, Boca Raton.

Samocha TM, H Guajardo, AL Lawrence, FL Castille, M Speed, DA McKee \& KI Page. 1998. A simple stress test for Penaeus vannamei postlarvae. Aquaculture 165: 233242.

Tseng YC \& PP Hwang. 2008. Some insights into energy metabolism for osmoregulation in fish. Comparative Biochemistry and Physiology Part C: Toxicology \& Pharmacology 148: 419-429.

Van Veld PA \& DE Nacci. 2008. Toxicity resistance. In: Di Giulio RT \& DE Hinton (eds). The toxicology of fishes, pp. 597-641. CRC Press, Boca Raton.

Yúfera M \& MJ Darias. 2007. The onset of exogenous feeding in marine fish larvae. Aquaculture 268: 53-63.

Received 9 January 2017 and accepted 4 April 2018

Editor: Claudia Bustos D. 